\section{Journal of Biochemistry Education}

Revista de Ensino de Bioquímica

Revista de Enseñanza de Bioquímica

Educational Innovations

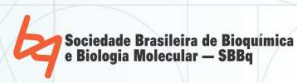

: 2318-8790

ISSN (until 2012): 1677-2318

\title{
Uso do Role-Playing Game (RPG) como complemento didático no ensino de
}

\section{Imunologia}

\author{
Use of Role-Playing Game (RPG) as a didactic complement in the teaching of Immunology
}

Matheus de Oliveira Lunardi Laureano ${ }^{1}$, Matheus Lewi Cruz Bonaccorsi de Campos ${ }^{1}$, Francisco de Menezes Cavalcante Sassi ${ }^{1}$, Martha Elisa Ferreira de Almeida ${ }^{1 *}$

${ }^{1}$ Campus Rio Paranaíba, Universidade Federal de Viçosa - UFV, Minas Gerais, Brasil

*e-mail: martha.almeida@ufv.br

\section{Resumo}

O Role-Playing Game (RPG) é definido como um jogo de interpretação de papéis, no qual os participantes podem jogar uns contra os outros, ou trabalharem juntos em prol de um objetivo. Assim, elaborou-se um jogo de RPG para trabalhar o conteúdo de Imunologia com crianças e adolescentes ( $5^{\mathrm{a}}$ a $8^{\mathrm{a}}$ série) onde as batalhas medievais, envolvendo criaturas fantásticas, se associam a elementos que compõem o Sistema Imunológico, como um xamã que representa um linfócito T. O mestre, neste caso o professor, guiará os participantes para ensinar o conteúdo de forma lúdica, ao longo de uma "guerra" dentro de uma pessoa. Os alunos controlarão os personagens responsáveis por atacar e defender o corpo (agentes infecciosos e glóbulos brancos, respectivamente) dispondo de um dado para a rolagem de suas ações no jogo. Como resultado, espera-se com este trabalho que o conteúdo de Imunologia seja fixado mais facilmente, de forma agradável e divertida.

Palavras-chave: método lúdico; Sistema Imunológico; ensino.

\begin{abstract}
RPG is defined as a Role-Playing Game, in which participants can play against each other, or work together towards a objective. Thereby, an RPG game was developed to work on the content of Immunology with children and adolescents (5th to 8th grade) where medieval battles, involving fantastic creatures, are associated with elements that make up the Immune System, such as a shaman representing an T lymphocyte. To teach Immunology through the RPG is primarily needed a master, will guide the participants to teach the content in a playful way, throughout a "war" within a person. The students who will control the characters responsible for attacking and defending the body (infectious agents and white blood cells, respectively) having a dice for the scrolling of their actions in the game. As a result, it is expected with this work that Immunology content will be more easily fixed in a fun and enjoyable way.
\end{abstract}

Keywords: playful method; Immune System; teaching. 


\section{Introdução}

O Role-Playing Game (RPG) é definido como um "Jogo de Interpretação de Papéis". O primeiro do gênero no mundo, denominado Dungeons \& Dragons, foi criado em 1974 nos Estados Unidos da América (EUA) [1]. Ele não se assemelha aos demais estilos de jogos, visto que o mesmo é aberto a diversas possibilidades. No papel de um personagem, o jogador está apto a dizer o que quer fazer, valendo-se de dados para efetivar ou não uma ação. Mesmo sendo um mundo aberto a várias possibilidades, existem regras que devem ser seguidas por todos os personagens, podendo ser moldadas pelo mestre que será o narrador do jogo [2].

Durante os preparativos de uma partida, a etapa de criação do personagem requer imaginação e bom senso, tanto dos jogadores quanto do mestre, que deve impor limites para haver equilíbrio entre a diversão e as regras do jogo, e não haver exageros e distorção dos seus objetivos. Após a descrição do ambiente da estória pelo mestre, cada jogador deve narrar sua ação, a qual deve ser coerente com as características de seu personagem, criando uma harmonia e vínculo entre todos os participantes, uma vez que um depende quase sempre da cooperação do outro [2]. Assim, o Role-Playing Game também pode ser definido como "um jogo de produzir ficção" [3].

Nos jogos cooperativos, os participantes deixam de ser adversários para jogarem juntos, sendo os objetivos e a diversão compartilhados por todos [4,5]. Tais jogos podem ser usados em sala de aula para diminuir conflitos como o bullying [6], e na socialização dos conhecimentos para a realização de tarefas que teriam dificuldade de realizarem sozinhos [7].

Várias estratégias têm sido pesquisadas para inovar o processo de ensino e aprendizagem [8]. A implantação de uma atividade prática na sala de aula necessita da compreensão dos mecanismos de aprendizagem, explorando estratégias metodológicas de forma a criar elementos que propiciem um ensino de boa qualidade [9]. 0 desenvolvimento cognitivo, a inteligência e a assimilação do indivíduo podem ser estimulados pela utilização de jogos, assim como sua aprendizagem [10,11].

O estilo de jogo Role-Playing Game ganhou força no Brasil como prática de ensino em 1997, com a publicação da primeira tese sobre este assunto [12]. O gênero pode ser utilizado como uma ferramenta didático-pedagógica abordando temas nas áreas de Ciências, Física, Matemática, História, Sociologia, Geografia, Informática, Artes, Línguas $[13,14,15]$, e quando bem explorado consegue ser aplicado desde a construção de novos 
conhecimentos até a fixação do conteúdo abordado em sala de aula [16]. O RPG Pedagógico vem sendo usado em várias partes do mundo, com destaque para o Brasil que tem sido um dos pioneiros na aplicação desta técnica [13].

Limberger e Silva [17] ressaltam que os jogos de RPG colaboram de forma positiva para a interação social, diminuição da timidez, além de possibilitar momentos de confraternização entre amigos, podendo também ser utilizado como ferramenta no atendimento psicoterápico [18]. Entretanto, alguns grupos de jogadores utilizam tal método de forma inadequada, gerando problemas que vão desde o vício até o confinamento, ou a morte de indivíduos [19].

Alguns jogos de RPG apresentaram bons resultados para a aquisição de conhecimentos no estudo do Sistema Digestório para graduandos de Licenciatura em Biologia [14]; no ensino de Química [20], Biologia Celular [21], Matemática [15], na modalidade de Ensino a Distância (EaD) [22]; e na formação de Enfermeiros, para o desenvolvimento do pensamento crítico-reflexivo [23]. Algumas obras literárias como os livros "O Cortiço", "Dom Casmurro" e "Memórias de um Sargento de Milícias" têm sido transpostas para jogos de RPG, cuja principal ação proposta ao jogador é clicar em objetos da cena para ler alguns trechos de cada livro [24].

Os jogos de RPG, além de atividade lúdica para crianças, adolescentes e até adultos, também possui potencial educativo com destaque para a expressão oral, corporal, para a aventura e também o desenvolvimento do conteúdo disciplinar ou interdisciplinar [20].

Durante uma partida é comum a utilização de elementos de combates medievais [2]. Assim, uma infecção bacteriana ou viral no corpo de um mamífero pode ser ilustrada fazendo-se alusão a uma guerra ou combate. Durante o desenrolar de uma guerra, acontece, cronologicamente, a invasão ou o ataque, a percepção do inimigo e o reconhecimento do seu poder de fogo, e posteriormente um pelotão de emergência será enviado para fazer as primeiras defesas. Terminado o reconhecimento do poderio inimigo, envia-se tropas especiais munidas de armas potentes para combater o inimigo. O campo de batalha passa a ser o corpo, onde os soldados são as células brancas (glóbulos brancos), as armas são os anticorpos (imunoglobulinas), e os recrutadores das armas são as citocinas. Neste contexto, os jogos podem ser utilizados para solucionar problemas, possibilitando o crescimento integral dos indivíduos [25], além de serem capazes de explorar sua criatividade e utilizar suas potencialidades de maneira integral.

Com base nos Parâmetros Curriculares Nacionais, que exigem conhecimentos de 
Imunologia no ensino fundamental (5 $5^{\mathrm{a}}$ a $8^{\mathrm{a}}$ série), e que os mesmos devem ser pautados na contextualização da realidade sociocultural e na interdisciplinaridade [26], este trabalho teve como objetivo elaborar um jogo de RPG a partir de uma história medieval lúdica, pautado em um conjunto de regras com alguns dos elementos que compõem o Sistema Imunológico, dando ênfase nos linfócitos B e T (imunidade adquirida).

\section{Desenvolvimento}

Elaborou-se um jogo a fim de trabalhar, em grupo, o conteúdo de Imunologia com estudantes de $5^{\text {a }}$ a $8^{\text {a }}$ série. Neste artigo não são apresentados dados avaliativos de sua aplicação em uma sala de aula, mas apenas norteia o plano de ensino no qual o professor poderá adotar para desenvolver suas atividades nas classes de aulas.

O jogo foi criado a partir do gênero de interpretação de papéis (RPG) com elementos de uma batalha típica do período medieval por sua fácil associação a monstros e magias. Para jogá-lo torna-se necessário, no mínimo, seis pessoas (um mestre e cinco jogadores), além das fichas autoexplicativas dos personagens (apêndice), um quadro com a relação "mundo real e equivalente no jogo" (Quadro 1), e uma estória fechada pronta.

Para explicar sobre a resposta Imunológica oriunda da mordida de um gato, uma estória jogável foi criada com personagens que ilustram os elementos que compõe tal Sistema (Quadro 1).

Quadro 1. Relações comparativas entre as partes do corpo humano e os componentes do Sistema Imunológico, com seus respectivos equivalentes durante a partida do jogo.

\begin{tabular}{|c|c|}
\hline Mundo real & Equivalente no jogo \\
\hline Corpo humano & O grande reino \\
\hline Sir Tom - o gato & Reino inimigo \\
\hline Cérebro & O rei \\
\hline Pele & País pertencente ao grande reinado \\
\hline Dedo mínimo do pé esquerdo & Primeira vila atacada - fonte da infecção \\
\hline Macrófagos & Espadachins \\
\hline Moléculas sinalizadoras (histamina e citocinas) & Trombetas reais \\
\hline Células dendríticas & Mensageiro \\
\hline Canais linfáticos & Ruas do reino "corpo humano" \\
\hline Linfonodos ingnais & Academia militar ingnal \\
\hline Linfócitos T auxiliares (CD4 ${ }^{+}$) & Xamãs \\
\hline Linfócitos T citotóxicos $\left(\mathrm{CD8}^{+}\right)$ & Assassinos \\
\hline Linfócitos B efetores & Magos que produzirão anticorpos \\
\hline Linfócitos B de memória & Magos muito sábios \\
\hline Anticorpos & Minions \\
\hline Vírus & Feiticeiro da mente \\
\hline Bactérias & Soldados de diferentes famílias \\
\hline Células no geral & Pessoas e habitantes dos reinos \\
\hline
\end{tabular}

Como os macrófagos são bem distribuídos pelos tecidos do corpo, e os primeiros 
combatentes do Sistema Imunológico, foram denominados "Espadachins", que estão sempre a postos e prontos para destruir o inimigo. Deve ser destacado sobre a "fagocitose", que é um processo no qual algumas células do Sistema Imunológico formam projeções semelhantes a tentáculos denominadas "pseudópodes", que envolvem e "engolem" o patógeno, onde será destruído na maioria das vezes dentro da célula.

A histamina e as citocinas são moléculas sinalizadoras responsáveis por atrair as células de defesa para o local da infecção, assim como as "trombetas reais" de um reino que avisam sobre a invasão inimiga. As citocinas conseguem aumentar o tamanho de um capilar, afrouxando as ligações entre as células que constituem o canal sanguíneo e consequentemente dilatando-o, o que facilitará a passagem de leucócitos da corrente sanguínea para o tecido infectado.

Isto poderia ser exemplificado para os alunos da seguinte forma: o professor encosta a porta deixando apenas um vão que deixa o giz passar, mas não o suficiente para deixar o apagador passar, destacando que alguns tipos celulares conseguem passar, mas outros não. Entretanto, após o afrouxamento do canal pelas moléculas sinalizadoras, ele abre um pouco a porta e deixa o apagador passar, demonstrando ainda que muitas unidades de giz poderiam passar ao mesmo tempo pelo espaço formado, com os outros tipos celulares maiores.

Outro fator que deve ser comentado é sobre o rolamento, que é o modo pelo qual os leucócitos se deslocam pelos vasos sanguíneos. O rolamento se dá com o auxílio de proteínas que realizam ligações fracas e diminuem a velocidade dessas células na corrente sanguínea, até que, através de uma ligação forte (com as integrinas) essas células param e atravessam o vaso sanguíneo. Isto poderia ser ilustrado para os alunos da seguinte forma: as ligações fracas são ganchos que pegam mas não prendem a célula, até que no momento que a célula estiver bem lenta é jogada uma rede (a ligação forte) que estaciona o rolamento da célula e a arrasta para a margem do vaso, fazendo com que ela atravesse o tecido.

As células dendríticas fagocitam um inimigo bacteriano e depois passam a carregar um fragmento do mesmo, denominado de epítopo (no jogo o epítopo será representado como um fragmento da armadura do inimigo), podendo usar um "mensageiro real" para fazer alusão a essas células. Com o epítopo em mãos, a célula dendrítica (mensageiro) percorre pelos canais linfáticos (que faz alusão a uma rua, interligando os linfonodos, local de armazenamento dos linfócitos T e B). Na partida, a "academia militar inguinal" (correspondente aos linfonodos inguinais) seria o linfonodo mais próximo do local da 
infecção, visto que o gato atacou o dedo mínimo do pé. Lá dentro estão os linfócitos não ativados, que são linfócitos T e B preparados para o combate, mas que ainda não foram estimulados. Assim, os mensageiros apresentarão o epítopo para um linfócito $T$ auxiliar $\left(C D 4^{+}\right)$que ficará responsável por ativar os linfócitos $B$ efetores, que são capazes de produzir anticorpos para lutar contra os patógenos; bem como os linfócitos $\mathrm{B}$ de memória que servirão para o combate em uma próxima batalha contra o mesmo tipo de patógeno.

Os linfócitos $\mathrm{T} \mathrm{CD8}^{+}, \mathrm{T} \mathrm{CD}^{+}$e os linfócitos $\mathrm{B}$ efetores conseguem reconhecer vários patógenos. Os linfócitos $\mathrm{T} \mathrm{CD}^{+}$usam um receptor de membrana especial, que reconhece o Complexo de Histocompatibilidade Principal (MHC) do tipo I existente nas membranas das células que estão infectadas pelo vírus, e por meio das perforinas e granzimas eliminam as células infectadas por vírus. Os linfócitos $\mathrm{T} \mathrm{CD4}^{+}$reconhecem o MHC do tipo II, encontrado em um fagócito que incorporou patógenos bacterianos (células dendríticas, macrófagos, e em algumas situações específicas os linfócitos B), estimulando os linfócitos B para produzirem uma reação Imunológica.

Os linfócitos B reconhecem os padrões moleculares associados aos patógenos com características lipídicas e polissacarídicas, e em cooperação com os linfócitos T CD4 ${ }^{+}$ reconhecem epítopos proteicos, enquanto o linfócito $\mathrm{T} \mathrm{CD}^{+}$reconhece os padrões moleculares associados a patógenos com características proteicas. Como os linfócitos têm características específicas de atuação na resposta Imunológica, os linfócitos T CD4 ${ }^{+}$ (xamãs) conseguem eliminar apenas patógenos com "armadura proteica"; entretanto, os linfócitos B (magos) conseguem, assim como outras células do Sistema Imunológico (como os soldados macrófagos), eliminar patógenos com características lipídicas, polissacarídicas e proteicas. Tais características poderiam ser tratadas de forma lúdica como armaduras ou roupas dos soldados em combate.

Os xamãs também podem aumentar a citotoxicidade de diversas células brancas através da liberação de citocinas. Pode-se explicar que eles utilizam um elixir para aumentar o poder das células de defesa, como o famoso espinafre do desenho animado Popeye (criado por Elzie Crisler Segar em 1929), ou o elixir mágico de Astérix e Obélix (quadrinho francês criado em 1959), deixando assim as células mais fortes contra seus adversários.

De forma lúdica foram destacados os micro-organismos que permeiam o ambiente, bem como a fonte da infecção que causaria a resposta Imunológica oriunda da mordida de um gato. Assim, o professor explicaria aos alunos como acontece a ativação do Sistema Imunológico por um vírus, um fungo ou uma bactéria; as substâncias liberadas 
pelo patógeno ou pela simples multiplicação do mesmo dentro do corpo humano. Deve-se destacar sobre os "antígenos", que são as partículas que desencadeiam uma resposta Imunológica. Mesmo os patógenos sendo microscópicos, eles geralmente têm um alto poder de multiplicação e podem causar danos locais em tecidos ou órgãos do corpo humano, promovendo, a longo prazo, prejuízos ao indivíduo. O professor poderia exemplificar este assunto, fazendo analogia a alguns tipos de diarreia que estão relacionadas com a presença de algumas bactérias patogênicas nos intestinos.

$\mathrm{Na}$ proposta do jogo elaborado, ocorreria ao mesmo tempo uma infecção viral e uma bacteriana, devendo ser ressaltado que alguns vírus possuem a capacidade de entrar em dormência (fazer a comparação com a hibernação dos ursos), ficando vários dias dentro do corpo sem que a pessoa fique doente, esperando a hora mais favorável, que no caso deste jogo, seria uma diminuição das respostas do Sistema Imunológico pelo ataque das bactérias.

É importante ressaltar que primeiramente o professor ministraria uma aula teórica com todos os termos técnicos adequados ao assunto, pois se ele trabalhar somente com a parte lúdica o ensino poderá se tornar incompleto, levando o aluno a imaginar que tal conteúdo ocorre apenas de maneira fantasiosa no corpo humano.

Para o início do jogo torna-se necessária a presença de um mestre e um mínimo de cinco jogadores, onde três deles jogarão como a defesa do Sistema Imunológico e dois coordenarão o ataque ao corpo humano, um como infecção viral e o outro como infecção bacteriana. Caso o jogo seja ministrado em uma turma grande, ela deve ser dividida em vários grupos, nos quais todos participarão simultaneamente do mesmo jogo. Poderá ser ranqueado como ganhadores por ordem de tempo de finalização da tarefa, ou seja, o primeiro grupo poderá terminar em $X$ minutos, o segundo em $Y$ minutos, e assim sucessivamente.

Cada papel seria representado por um único aluno ou por duplas, permitindo que o RPG fosse adaptado às atividades de salas de aula, que geralmente possuem de 20 a 50 alunos. Cavalcanti e Soares [20] destacam que um jogo de RPG pode ser finalizado em uma única sessão com duração de 1 a 4 horas, ou durar semanas e até meses, dependendo do assunto trabalhado. Sugere-se que a partida proposta (dando ênfase nos linfócitos B e T - imunidade adquirida) tenha a duração de duas horas, para não atrapalhar $\mathrm{o}$ andamento de outras disciplinas ministradas.

Seis dados comuns de seis lados (D6) serão utilizados nesta atividade em cada grupo, e para maior interação entre os jogadores, pode-se pedir que cada jogador 
desenhe seu próprio personagem, por exemplo um linfócito T ou um vírus, nas fichas de personagem que encontram-se no apêndice deste artigo. Tal fato será importante para despertar a capacidade criativa de cada aluno como base nos conhecimentos teóricos adquiridos.

A "letalidade" de cada classe de personagem e seu respectivo funcionamento nas partidas será explicada no verso de cada ficha, que deverá ser dobrada na região pontilhada para dar maior ludicidade ao evento proposto. Para identificar quem ganhou cada turno, será contado o número de pontos de letalidade causados pelos grupos, atacante e defensor, no qual o possuidor do maior número de danos ganhará aquele turno.

Informações para o mestre

O professor, que geralmente assume o papel de mestre no jogo, deve dividir a turma em grupos para evitar que cada aluno crie seu personagem e atrase 0 desenvolvimento do jogo [27], visto que a atividade não deve ultrapassar o tempo previsto da aula. Para facilitar este processo, serão disponibilizadas fichas prontas para que os alunos as utilizem. O mestre também deve ser imparcial, mantendo a harmonia do jogo sem priorizar nenhum dos grupos, explicando as regras sempre com boa interpretação, e fazendo as devidas alusões ao Sistema Imunológico.

Segundo Rezende e Coelho [28], é importante o rompimento da passividade imposta pelas atividades escolares, visto que alguns alunos não querem participar do jogo no início da atividade, mas posteriormente tornam-se interativos. Moratori [29] ressalta que os educadores possuem dificuldade em aplicar jogos em sala de aula, pela necessidade prévia de planejamento e compatibilidade com a carga horária executada por professores da rede pública, mas o uso de jogos pode ser avaliativo, revisor, introdutório ou reforçador do conteúdo aplicado, entretanto seu uso constante deve ser ponderado, pois o impacto causado pode ser decorrente de sua inconstância.

O mestre permitirá as ações dos personagens, julgando-as como válidas em relação aos critérios básicos de como o Sistema Imunológico funciona, fazendo as devidas explicações quando necessário: apenas um linfócito T CD8 ${ }^{+}$(classe - assassino) tem a capacidade de destruir células infectadas por vírus (classe - feiticeiro da mente), logo, um jogador que controla um linfócito T CD4+ (classe - xamã) não poderá realizar esta ação. Além disso, deverá explicar cada ação exercida pelo Sistema Imunológico ao 
longo das rodadas de jogo, tomando como exemplo o funcionamento da histamina quando esta for utilizada ou o reconhecimento de um patógeno quando se der tal ação. Atividades trabalhadas no RPG promovem a interação e a participação ativa dos alunos, inserindo-os em condições problemáticas, porém motivadoras e importantes na aprendizagem dos estudantes [30].

Seguindo o formato RPG de jogo, toda ação requer a jogada de um dado (D6) para identificar sucesso ou falha e sua interpretação, pois o aluno é quem controla um personagem. Para criar um melhor ambiente do jogo, sugere-se que o mestre mude a voz, levante-se, gesticule e coloque músicas de fundo. Tal sugestão é muito útil quando se possui apenas um grupo de alunos jogando o RPG, pois caso a turma seja dividida em vários grupos tais ações do professor são desnecessárias, visto que poderiam confundir os participantes ou até mesmo diminuírem sua atenção, uma vez que cada indivíduo terá um tempo diferente para interpretar um assunto e dar uma resposta.

No jogo elaborado, a partida consiste de cinco etapas de combate, onde ganhará o jogo o grupo que obtiver três vitórias ou quatro derrotas, obtendo vitória na quinta etapa, o que motivará os jogadores a não desistirem ao final da terceira rodada. Cada etapa equivale a uma rodada de ataque do invasor e da defesa. Para ganhar uma etapa é necessário causar mais danos na forma de "letalidade" que o oponente, sendo a letalidade de cada célula explicada na ficha dos personagens.

O professor deve explicar sobre os tipos celulares, suas funções e morfologia para que o participante do jogo tenha em mente como será o seu personagem.

\section{Informações para os alunos}

Cada aluno irá escolher um dos grupos (Quadro 2), e as informações sobre os personagens e suas instruções do jogo que estarão discriminadas nas fichas.

Quadro 2. Relações comparativas entre os participantes do combate e seus representantes biológicos.

\begin{tabular}{|l|l|}
\hline Participantes do combate & Representantes biológicos \\
\hline Linha de ataque bacteriano & Streptococus pneumoniae, Streptococus pyogenes, Enterococcus faecium \\
\hline Linha de ataque viral & Zika virus, Rubella virus \\
\hline Linha de defesa & Linfócitos T (CD4 ${ }^{+}$e CD8 ${ }^{+}$), linfócitos B \\
\hline
\end{tabular}

O jogo 
- $\quad 1^{\text {a }}$ Etapa: o mestre explicará sobre a defesa Imunológica realizada pelos linfócitos $\mathrm{T}$ e $\mathrm{B}$, utilizando de forma misteriosa e envolvente o seguinte enredo, para prender a atenção dos alunos e introduzir o assunto:

Em um nefasto reino, conhecido como "Corpo Humano", residem diversos habitantes. Todos os grandes países vivem em prol do grande rei, "Cérebro"! É nele que todas as decisões são pensadas e executadas.

O grande reinado é protegido pelo maior país de todos, chamado "Pele". A Pele é a primeira defesa do reinado (bem como a primeira barreira imunológica), sendo que dificilmente as forças inimigas conseguem penetrá-la. Em um dia calmo e monótono, o grande reino "Corpo Humano" estava em sua incursão diária ao quintal, o que ele não esperava era um ataque surpresa... Um grande felino chamado "Sir Tom", que é de um dos reinados vizinhos, proferiu uma investida contra o "Corpo Humano" e o acertou. Rapidamente o Cérebro interpretou o sinal de perigo e dor, e preparou a defesa.

Posteriormente, o Cérebro recebeu notícias de um dos seus países, o "Pé", dizendo que uma pequena parte do país (um pedaço de Pele) foi destruída. Sabendo do poderio de seu exército, o Cérebro não se preocupou com o ocorrido. Uma pena, pois ele mal sabia a violência da guerra que estava para acontecer.

Agora olharemos mais internamente o reino, observando como a população da pequena vila "Mínimo esquerdo ou mindinho esquerdo" está em relação a este ataque.

As armas afiadas do felino possuíam diversos invasores, alguns soldados bacterianos de diversos exércitos e alguns espiões virulentos escolhendo a hora certa para agir.

Os primeiros soldados, que normalmente estão na defesa, são os Espadachins (Macrófagos) que abaterão alguns soldados invasores e chamar, usando trombetas de histamina e citocinas, outros guerreiros para defender a vila.

Para que os linfócitos sejam treinados corretamente contra seu inimigo específico, os mensageiros dendríticos precisam obter um brasão de cada exército que está atacando o reinado. Como eles são eficientes conseguem o brasão facilmente. Assim, os mensageiros correrão em direção ao "canal linfático", sua forma de deslocamento que existe dentro do reinado e que leva todos que entram nele pela linfa até a "Academia Militar Inguinal", ou seja, a academia militar mais próxima da região de ataque. Nesse lugar se encontram os soldados não ativados, que são treinados, mas que ainda não se especificaram na luta contra um determinado exército. Lá dentro serão treinados os 
soldados específicos, os magos (linfócitos B) e os assassinos e xamãs (linfócitos T).

Nesta etapa, cada jogador que escolheu controlar os soldados linfócitos $T$ irá escolher entre duas especializações: linfócito assassino ( $T$ CD8 ${ }^{+}$) ou linfócito xamã ( $T$ $\left.\mathrm{CD} 4^{+}\right)$.

Retorna-se ao mestre:

Agora que o mensageiro entregou o brasão na academia militar, ele voltará ao campo de batalha para continuar reconhecendo os inimigos localizados no campo de batalha e a guerra começará.

- $\quad 2^{a}$ Etapa: iniciará com a batalha dos vírus, na qual todos os participantes que escolheram os vírus como personagem jogarão os dados, conforme a descrição de sua ficha e checar a letalidade do seu dano. Em seguida ocorrerá a batalha das bactérias, na qual todos os participantes que escolheram as bactérias como personagem irão jogar os dados, conforme a descrição de sua ficha e checar a letalidade do seu dano. Posteriormente começará a batalha dos linfócitos que será iniciada com os xamãs, onde os jogadores que escolheram estes personagens poderão decidir entre atacar ou usar sua habilidade especial descrita nas fichas. Finalmente ocorrerá a jogada dos assassinos, da mesma forma ocorrida com os vírus e bactérias e, no final de cada turno de combate, jogamse os magos (da mesma maneira que os xamãs).

- $3^{\text {a }}$ Etapa: somará os pontos de letalidade do turno de combate.

- 4⿳亠口冋 Etapa: $2^{\circ}$ turno de combate.

- $5^{\text {a }}$ Etapa: repetirá a 2 $2^{a}$ e $3^{\text {a }}$ etapa para os turnos de combate 3,4 e 5.

- 6a Etapa: terminará o jogo.

No final dos 5 turnos, caso a Resposta Imunológica obtenha sucesso, ou seja, os jogadores que defendem o reinado obtiverem o maior número de letalidade no turno, todos os jogadores de defesa receberão a magia "Memória", que nos casos de uma invasão futura realizada (outra partida jogada) pelos mesmos tipos de atacantes, as células de defesa irão ter o dobro da eficácia contra os atacantes (o dobro da letalidade). Caso a vitória seja dos invasores, um dos jogadores que controla as bactérias pode escolher entre usar uma armadura (de lipídios ou polissacarídios), podendo receber ataques dos magos, reduzindo sempre o dano de letalidade desses atacantes em 1, devido a armadura.

Segundo Soares et al. [23], o jogo de RPG pode possibilitar aos alunos o desenvolvimento da autonomia e do pensamento crítico para resolver situações-problema do dia-a-dia, bem como de sua formação profissional, quando adotado nos cursos de graduação. Randi e Carvalho [21] ressaltam que as aulas que utilizam o RPG são tão 
eficientes quanto as tradicionais, são bem-aceitas pelos alunos e possui como característica positiva o fato da metodologia dar a chance de todos participarem, e de aprenderem ativamente, bem como ter uma melhor retenção do conhecimento aprendido após um (01) ano da realização da atividade. Almeida e Santos [31] identificaram que universitários tiveram um aumento da assimilação do conteúdo de Imunologia, mediante a utilização de recursos lúdicos (música e teatro).

Para avaliar a eficácia desta metodologia proposta neste estudo, sugere-se cada aluno responda individualmente um questionário contendo 10 perguntas sobre o assunto abordado no jogo do RPG, sendo tal avaliação realizada uma semana antes e uma semana depois do jogo. Almeida e Santos [31] relatam que metodologias lúdicas promovem o conhecimento e sua fixação, que podem ser avaliadas via a aplicação de questionários.

Como limitação desta metodologia proposta, poderá ocorrer a desunião e/ou a rivalidade entre os grupos ou membros do mesmo grupo. Assim, uma boa orientação do professor poderá contornar tal situação, promovendo a conciliação das ideias em um mesmo grupo, e entre os grupos rivais, sempre ressaltando que o objetivo deste jogo é fomentar o conhecimento e a diversão entre seus jogadores.

\section{Considerações finais}

Visto que o jogo de RPG desenvolve várias habilidades como a leitura e a escrita, a imaginação e criatividade, o trabalho em grupo, a resolução de vários tipos de problemas, o raciocínio lógico, a concentração, o respeito às regras e a todos os envolvidos, esperase que este conteúdo de Imunologia seja fixado mais facilmente, de forma agradável e divertida pelos estudantes de $5^{\mathrm{a}}$ a $8^{\mathrm{a}}$ série.

Sugere-se que sejam realizadas várias partidas para trabalhar todo o conteúdo de Imunologia, e que antes de iniciar cada partida sejam discutidas as regras de RPG, com destaque para as técnicas de narração da estória elaborada, para a criação de uma ambientação adequada e para as aventuras dos alunos, nas quais deve ser envolvida a pesquisa do assunto, bem como avaliar a satisfação dos mesmos através de questionários. 


\section{Referências Bibliográficas}

[1] Cassaro M. Manual 3D\&T Alpha. Porto Alegre: Jambô, 2008.

[2] Cassaro M, Dei Svaldi G, Caldela L. Tormenta RPG. Porto Alegre: Jambô, 2015.

[3] Rodrigues S. Role playing game e a pedagogia da imaginação no Brasil: primeira tese de doutorado no Brasil sobre o role playing game. Rio de Janeiro: Bertrand Brasil, 2004.

[4] Brotto FO. Jogos cooperativos: o jogo e o esporte como um exercício de convivência. Dissertação [Mestrado em Educação Física]-Faculdade de Educação Física, Universidade Estadual de Campinas, Campinas. 1999.

[5] Brandl Neto I, Lima PMS. Jogos cooperativos. Caderno de Educação Física: Estudos e Reflexões, 2002; 4(8):107-118.

[6] Bomfim DL et al. Ocorrência de bullying nas aulas de Educação Física em uma escola do Distrito Federal. Pensar a Prática, 2012; 15(2):302-317.

[7] Martini RG. Jogos cooperativos na escola: a concepção de professores de educação física. Dissertação [Mestrado em Psicologia da Educação]-Pontífica Universidade Católica de São Paulo, PUC-SP. 2005.

[8] Riyis MT. SIMPLES: Sistema inicial para mestres - professores lecionarem através de uma estratégia motivadora. São Paulo: Editora do Autor, 2004.

[9] Cabrera WB. A ludicidade para o ensino médio na disciplina de biologia: contribuições ao processo de aprendizagem em conformidade com os pressupostos teóricos da Aprendizagem Significativa. Dissertação [Mestrado em Ensino de Ciências e Educação Matemática]-Universidade Estadual de Londrina, Londrina. 2007.

[10] Piaget JWF. Fazer e compreender. São Paulo: Melhoramentos EDUSP, 1978.

[11] Vygotsky LS. Pensamento e linguagem. Brasil: Ed Ridendo Castigat Mores, 1979. Acesso em 04 de agosto de 2017. Disponível em: www.ebooksbrasil.org/adobeebook/vigo.pdf.

[12] Xavier R. RPG e o ensino de história: diálogos e perspectivas. Revista Encontros de Vista, 2011;7:8693.

[13] Amaral RR, Bastos HFBN. O Roleplaying Game na sala de aula: uma maneira de desenvolver atividades diferentes simultaneamente. Revista Brasileira de Pesquisa em Educação em Ciências, 2011;11(1):103-122.

[14] Oliveira Neto AA, Benite-Ribeiro SA. Um modelo de role-playing game (RPG) para o ensino dos processos da digestão. Itinerarius Reflectionis, 2012; 2(13):1-15.

[15] Rosetti $\mathrm{Jr} \mathrm{H}$ et al. O jogo na educação matemática: desenvolvimento de um RPG para trabalhar o conceito de moeda no ensino fundamental. HOLOS, 2015; 8(31):113-121.

[16] Vasques RC. As potencialidades do RPG (Role Playing Game) na educação. Dissertação [Mestrado em Educação Escolar]-Departamento de Didática, Programa de Pós-graduação em Educação Escolar da Unesp, Universidade Estadual Paulista "Júlio de Mesquita Filho", Araraquara. 2008.

[17] Limberger LS, Silva JC. Os role playing games (RPGS) como uma ferramenta em psicoterapia: um estudo de caso. Boletim de Psicologia, 2014; LXIII(139):193-200.

[18] Araujo RB, Oliveira MMA, Cemi J. Desenvolvimento de Role-Playing Game para prevenção e tratamento da dependência de drogas na adolescência. Psicologia: Teoria e Pesquisa, 2011;27(3):347-356.

[19] Saldanha AA, Batista JRM. A concepção do Role-Playing Game (RPG) em jogadores sistemáticos. Psicologia Ciência e Profissão, 2009; 29(4):700-717. 
[20] Cavalcanti ELD, Soares MHFB. O uso do jogo de roles (roleplaying game) como estratégia de discussão e avaliação do conhecimento químico. Revista Electrónica de Enseñanza de las Ciencias, 2009; $8(1): 255-282$.

[21] Randi MAF, Carvalho HF. Aprendizagem através de Role-Playing Games: uma abordagem para a educação ativa. Revista Brasileira de Educação Médica, 2013; 37(1):80-88.

[22] Rosa M. Pesquisa qualitativa em Educação Matemática a distância: aspectos importantes do uso do Role Playing Game como procedimento metodológico de pesquisa. Educar em Revista, 2012; 45:231-258.

[23] Soares AN et al. Role playing game (RPG) como estratégia pedagógica na formação do enfermeiro: relato da experiência de criação do jogo. Texto \& Contexto Enfermagem, 2015; 24(2):600-608.

[24] Zamariam FS. O RPG como alternativa metodológica para o ensino da leitura literária nas aulas de língua portuguesa. In: XI SEMINÁRIO DE PESQUISA EM CIÊNCIAS HUMANAS - SEPECH Humanidades, Estado e desafios didático-científicos. Londrina, 2016. Acesso em 04 de agosto de 2017. Disponível em: http://www.proceedings.blucher.com.br/article-details/o-rpg-como-alternativa-metodolgica-para-o-ensino-daleitura-literria-nas-aulas-de-Ingua-portuguesa-23676.

[25] Amaral JD. Jogos cooperativos. 4. ed. São Paulo: Phorte, 2009.

[26] Brasil. Secretaria de Educação Fundamental. Parâmetros curriculares nacionais: ciências naturais. Brasília: MEC/SEF, 1998.

[27] Marcatto A. Saindo do quadro. São Paulo: São Paulo, 1996.

[28] Rezende M, Coelho CPA. Utilização do Role-Playing Game (RPG) no Ensino de Biologia como ferramenta de aprendizagem investigativo/cooperativa. In: XXV CONADE, Congresso Nacional de Educação de Jataí - CAJ/UFG. Jataí, 2009. Acesso em 04 de agosto de 2017. Disponível em: http://www.academia.edu/3500258/A_Utiliza\%C3\%A7\%C3\%A3o_do_Role-

Playing_Game_RPG_no_Ensino_de_Biologia_como_Ferramenta_de_Aprendizagem_Investigativo_Cooper ativa.

[29] Moratori PB. Por que utilizar jogos educativos no processo de ensino aprendizagem? Rio de Janeiro, 2003. Acesso em 04 de janeiro de 2017. Disponível em: http://www.nce.ufrj.br/ginape/publicacoes/trabalhos/t_2003/t_2003_patrick_barbosa_moratori.pdf.

[30] Ferreira JHBP et al. Aprendendo sobre a relação presa-predador por meio de jogos pedagógicos. Departamento de Fisiologia - UNESP/ Instituto de Biociências/Botucatu - São Paulo, 2010. Acesso em 04 de agosto de 2017. Disponível em: http://www.unesp.br/prograd/PDFNE2005/artigos/capitulo\%2010/aprendendopresapredador.pdf.

[31] Almeida MEF, Santos VS. Ensino de Imunologia pela incorporação do conhecimento pelo teatro e a música. Revista de Ensino de Bioquímica, 2015;13(3):6-21. 


\section{Apêndice}

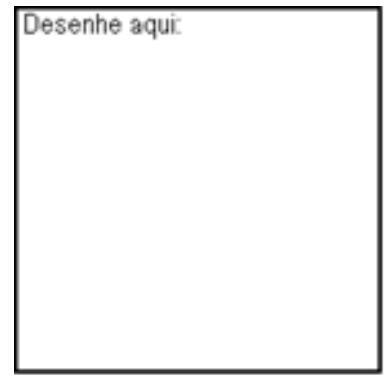

Espécie: Streptococcus pneumoniae Classe: Debuffer

Habilidade: A cada 6 tirado no dado, faz com que os ataques do Sistema Imunológico perca 1 ponto de letalidade permanente.

Letalidade: $1 / 2$ arredondado para cima por valor no dado. Ou seja, 1 e 2 no dado causam 1 de letalidade, 3 e 4 causam 2, e 5 ou 6 proferem 3 de letalidade.
A bactéria da espécie Streptococcus pneumoniae é a causadora da Pneumonia. Alguns dos sintomas são febre de 39 a $40^{\circ} \mathrm{C}$, suor frio e calafrios, respiração rápida e curta, tosse seca ou com produção de catarro, dores no peito ou tórax. Além de dispneia (dificuldade para respirar), diarreias, vômitos, náuseas e fadiga. Neste jogo, a Streptococcus pneumoniae foi colocada como debuffer, pois no RPG, os debuffers são uma classe usada para prejudicar o inimigo, não necessariamente através de danos, mas diminuindo ou debilitando status, reduzindo a força ou velocidade de um guerreiro para que outros personagens do grupo consigam derrotá-lo.

A habilidade especial de Streptococcus pneumoniae é, a cada número 6 conseguido no dado, cada equipe inimiga irá receber -1 nos valores de letalidade conseguidos em suas jogadas até o fim da partida, este efeito acumula -1 para cada 6 conseguido, simbolizando um enfraquecimento do sistema imune por ação da bactéria.

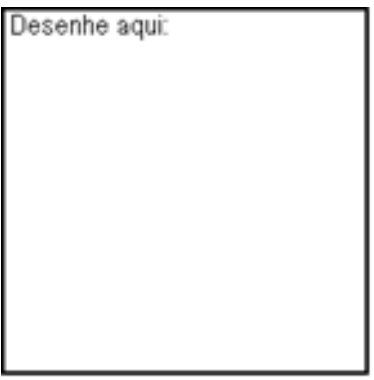

Espécie: Streptococcus pyogenes

\section{Classe: Bárbaro}

Habilidade: Cada 6 tirado no dado, faz com que seu ataque tenha o dano da letalidade duplicado.

Letalidade: 2 pontos por valor no dado.

\section{Invasão Bacteriana}

A bactéria da espécie Streptococcus pyogenes é causadora da faringite bacteriana comum, mas também pode ser responsável por doenças mais graves como a escarlatina. Para este jogo, a Streptococcus pyogenes foi colocada como um bárbaro. No RPG, o bárbaro é uma classe simples de se jogar, apesar disso, ele causa um dano considerável, podendo ser um verdadeiro desastre para a equipe inimiga, assim como a Streptococcus pyogenes.

A habilidade especial de Streptococcus pyogenes é, a cada número 6 conseguido no dado, o dano causado naquele ataque é dobrado, assim, um 6 equivale à 24 de dano de letalidade. 


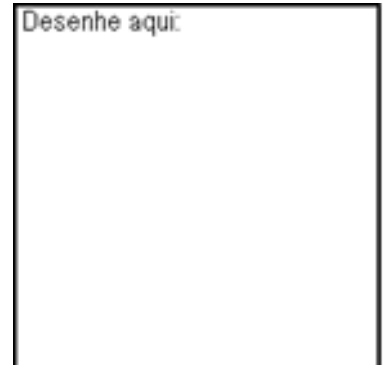

Espécie: Enterococcus faecium Classe: Berserk

Habilidade: Após 2 turnos vitoriosos, se transforma em uma superbactéria, onde sua letalidade é dobrada.

Letalidade: 1 ponto por valor no dado.
A bactéria da espécie Enterococcus faecium é capaz de causar naturalmente grande dano ao corpo humano, principalmente por causa da febre. Por ser comum em hospitais e infecções hospitalares, esta bactéria entra em contato constante com diversos antibióticos o que pode acabar selecionando uma cepa resistente a vários antibióticos, onde ela passa a ser chamada de "superbactéria" e fica difícil de combatê-la, podendo se espalhar rapidamente caso um paciente não seja isolado e podendo levá-lo a óbito. A Enterococcus faecium foi colocada neste jogo como um berserk, classe esta que causa dano contínuo no RPG, aumentando sua força para lutar mais e mais.

A habilidade especial da Enterococcus faecium é dobrar seu dano de letalidade caso sua equipe ganhe dois turnos, ou seja, o número no dado $\times 2$. Caso um terceiro turno seja ganho, o dado de letalidade passa a ser $x 3$, onde um 3 no dado equivale à 9 de dano de letalidade.

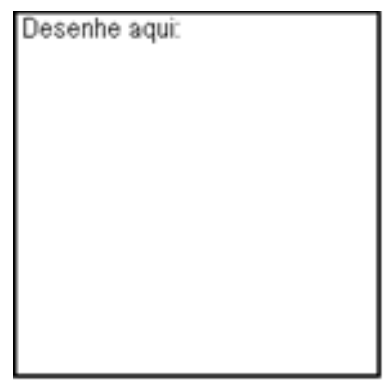

Espécie: Zika vírus

Classe: Feiticeiro da mente

Habilidade: Quando atacados reduzem a letalidade dos assassinos em 2 pontos.

Letalidade: 1 ponto por valor no dado.
O Zika vírus foi colocado como um feiticeiro da mente neste jogo devido ao funcionamento de um vírus, que infecta as células e depois as obriga a trabalhar para ele. Nos jogos eles possuem a habilidade natural de enfeitiçar os outros a seu favor, podendo enfeitiçar muitos em pouco tempo, logo ele age por terceiros e são difíceis de encontrar e demoram a morrer. Isso faz alusão à dificuldade que se tem em combater alguns tipos de vírus, pois conforme uma cepa de vírus é destruída por algum medicamento, outra cepa mais resistente acaba sendo selecionada, e então a doença pode retornar, neste caso, um soldado enfeitiçado que é destruído pode ser substituído por outro, bastando o feiticeiro agir.

O Zika vírus tem a letalidade de 1 ponto, para cada valor no dado. Sua habilidade especial consiste em reduzir 2 pontos da letalidade dos assassinos a cada golpe recebido. Ludicamente, cada ponto de letalidade se refere à um cidadão do reino sob controle do feiticeiro. 


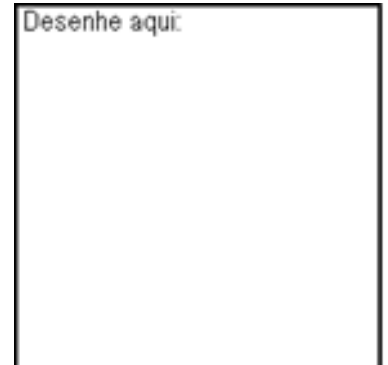

\section{Invasão Viral}

Espécie: Rubella vírus

Classe: Monge

Habilidade: Rápida multiplicação. A cada 6 obtido no dado ele pode jogar um dado adicional de letalidade (efeito não cumulativo).

Letalidade: 1 ponto por valor no dado.
O Rubella vírus é o vírus causador da Rubéola. Alguns de seus sintomas são: febre, manchas avermelhadas e dores pelo corpo, dor nos olhos, dificuldade ao engolir, nariz entupido e inchaço nos pés. Neste jogo, o Rubella vírus foi colocado como um monge, classe que pode causar muitos danos em curto período de tempo. Sua habilidade especial é que, a cada número 6 obtido no dado, o jogador pode jogar um novo dado para causar mais dado, onde já se tem os 6 pontos do dado anterior. Mas, caso o jogador obtenha 6 novamente não poderá jogar outro dado, de forma que a letalidade máxima obtida é 12 pontos, 6 de um dado e 6 do outro.

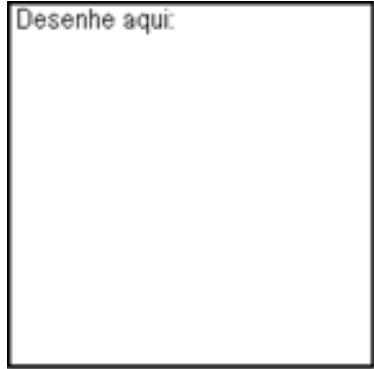

\section{Sistema Imunológico}

Tipo celular: Linfócito $T$ citotóxico ( $T$ $\mathrm{CD}^{+}$)

Classe: Assassino

Função (lúdica): Reconhecer e eliminar os indivíduos sobre o controle mental dos vírus.

Habilidade: 2 de letalidade aumentada a cada 10 pontos de letalidade causados. Letalidade: 1 ponto por valor no dado.
O linfócito $T C D 8^{+}$é responsável por eliminar células que estão infectadas por vírus. Assim, seu dano é voltado para o combate contra vírus, mesmo que seja necessária a eliminação de células do próprio organismo. Assim, o linfócito $\mathrm{T} \mathrm{CD}^{+}$foi colocado como um assassino, pois no RPG o assassino é uma classe impiedosa, que irá atacar seus próprios aliados por seu interesse ou bem maior.

O linfócito $\mathrm{T} \mathrm{CD8}{ }^{+}$tem uma letalidade equivalente ao valor tirado no dado, entretanto, cada um de seus pontos de letalidade neutraliza a letalidade causada pelo feiticeiro da mente. Exemplos: O feiticeiro causou 10 de letalidade, o assassino 9, então o feiticeiro causou 1 e o assassino 0 na contabilização final. $O$ feiticeiro causou 8 de dano e o assassino 12, então o resultado verdadeiro é 0 para feiticeiro e 4 para 0 assassino. Isto não afeta a habilidade do personagem, que tem sua letalidade aumentada em +2 a cada 10 pontos de dado, sendo que esses +2 entrarão em vigor na próxima rodada. 


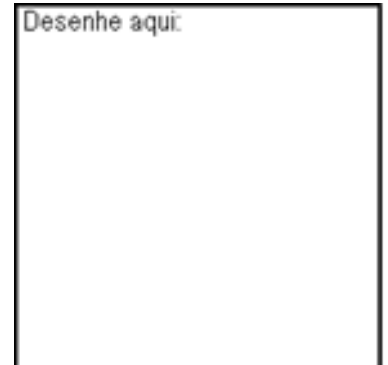

\section{Sistema Imunológico}

Tipo celular: Linfócito $\mathrm{T}\left(\mathrm{T} \mathrm{CD4} 4^{+}\right)$

Classe: Xamã

Função (lúdica): Reconhecer e eliminar indivíduos com armadura proteica.

Habilidade: Ganha 1 de letalidade a cada 10 pontos causados, aumentando +10 poder dos magos e assassinos a cada 15 pontos.

Letalidade: 2 pontos por valor no dado (+1 a cada 10 pontos).

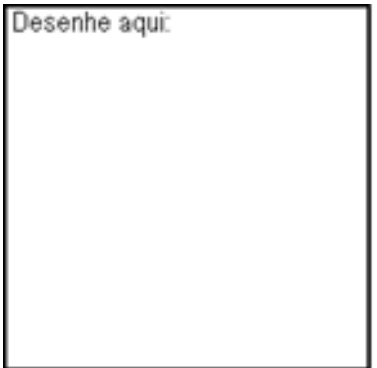

\section{Sistema Imunológico}

Tipo celular: Linfócito B

Classe: Mago

Função (lúdica): Reconhecer e eliminar indivíduos com armadura de lipídio, polissacarídio ou proteína e produzir anticorpos.

Habilidade: Pode usar a magia que, no turno seguinte, garante 10 pontos de letalidade e diminui 1 ponto da letalidade total do inimigo na rodada de somatório.

Letalidade: 1 ponto por valor no dado.
O linfócito $\mathrm{T} \mathrm{CD}^{+}$é responsável por aumentar a citotoxicidade das células do Sistema Imunológico. Assim, ele foi colocado como um Xamã, classe conhecida por ajudar seus aliados e causar danos através de magias.

$\mathrm{O}$ linfócito $\mathrm{T} \mathrm{CD} 4^{+}$tem uma letalidade de 2 pontos por número no dado, logo, um valor de 3 no dado equivale a 6 de dano de letalidade.

A habilidade especial dele pode aumentar sua letalidade e dos aliados conforme descrito no campo habilidade ou então, gastar um turno (não fazer ações de ataque) para aumentar permanentemente a letalidade dos assassinos, magos e dele mesmo em 2 pontos. No caso dos assassinos, essa letalidade não pode ser diminuída pelos vírus e no caso dos magos esta ação configura a ativação do linfócito B que irá produzir anticorpos. Esta habilidade pode ser usada apenas $1 \mathrm{vez}$.

O linfócito B é responsável por eliminar bactérias com epítopos com características lipídicas, polissacarídicas e proteicas em sua membrana, e após ativação pelo linfócito $\mathrm{T} \mathrm{CD4}{ }^{+}$, é capaz de se diferenciar em um plasmócito, onde passa a produzir anticorpos. No RPG, o mago é uma classe muito versátil, complexa, que possui diversas habilidades, podendo também invocar criaturas para lutar por ele, assim como o linfócito $B$ em sua forma de plasmócito faz na criação de anticorpos.

O linfócito $B$ possui letalidade de 1 ponto por valor no dado, entretanto, esta letalidade pode ser aumentada pelo Xamã.

A habilidade especial do linfócito $B$ é abdicar se seu turno e assim garantir 10 pontos de letalidade no próximo turno + o dado, além disso, diminui 1 ponto da equipe inimiga na rodada de soma. 